\title{
Detský hrdina v stredoeurópskych literatúrach s tematikou vojny a šoa'
}

\section{Child Hero in Central European Literatures with the Theme of War and the Shoah}

\author{
Monika Adamická
}

(Nitra, Slovensko)

\begin{abstract}
Abstrakt:
Článok pojednáva o vybraných dielach literatúry pre deti a mládež českej, slovenskej a pol'skej proveniencie, v ktorých sa autori zamerali na obdobie druhej svetovej vojny a konečného riešenia židovskej otázky. Špecificky sa sústredí na dielo slovenského autora židovského pôvodu píšuceho česky Ladislava Grosmana $Z$ pekla štěstí, denník pol'ského židovského chlapca Dávida Rubinowicza Dávidkov denník s tematikou šoa, diela slovenských autorov Juraja Špitzera Biele oblaky s tematikou SNP a Vincenta Šikulu Erikine lalie, v ktorej zobrazil holokaust na Slovensku. Príspevok sa zameriava najmä na dva aspekty týchto diel, a to symboliku detskej nevinnosti, ktorá tu stojí v ostrom kontraste s mašinériou vojnového vraždenia a smrti Židov v koncentračných táboroch, a motív straty detstva pod vplyvom prežitých hrôz.
\end{abstract}

\section{Klúčové slová:}

literatúra pre deti a mládež; holokaust; druhá svetová vojna; Slovenské národné povstanie

\section{Abstract:}

The article deals with selected works of literature for children and youth of Czech, Slovak and Polish provenance, in which the authors focused on the period of the World War II and the Final Solution to the Jewish Question. It will specifically focus on the work of the Slovak author of Jewish origin writing in Czech Ladislav Grosman

1 Štúdia vznikla v rámci riešenia projektu VEGA 1/0143/21 Antisemitské etnické stereotypy v médiách a literatúre krajín $\mathrm{V}_{4}$. 
The Devil's Own Luck (Z pekla štěstí) and the diary of the Polish Jewish boy The Diary of David Rubinowicz (Dávidkov denník) with the issue of the Shoah, and works by Slovak authors Juraj Špitzer White Clouds (Biele oblaky) with the theme of the Slovak National Uprising and Vincent Šikula The Lilies of Erika (Erikine lalie), in which he portrayed the Holocaust in Slovakia. The article deals mainly with two aspects of these works, namely the symbolism of childhood innocence, which stands in sharp contrast to the machinery of war murder and death of Jews in concentration camps, and the motif of the loss of childhood under the influence of horrors the main characters experienced.

\section{Key words:}

children's and youth literature; Holocaust; World War II.; Slovak National Uprising

Holokaust sa s odstupom desatročí od konca druhej svetovej vojny stal kolektívnou traumou a vo všeobecnosti reprezentuje nehumánnost' a pokrivenie morálnych hodnôt. Tematika druhej svetovej vojny a holokaustu sa stala námetom mnohých literárnych a filmových spracovaní ${ }^{2}$ a dostala sa aj do tvorby pre deti a mládež s cielom približit detskému recipientovi negatívne javy nedávnej minulosti detsky akceptovatelným jazykom a štýlom. Cielom literatúry pre deti a mládež reflektujúcej uvedenú problematiku je podla Lydie Kokkoly tlmočenie informácií a materiálu, ktorý bol z hladiska miliónov obetí označený za nevhodný na reprezentovanie pre detského čitatela. ${ }^{3} \mathrm{~V}$ istom zmysle možno tvrdit', že akékolvek písanie o holokauste pre deti narúša isté prísne tabu - aby sa deti nevystrašili hororovými príbehmi vychádzajúcimi z reality. Literatúra o holokauste pre deti je preto kombináciou náročného predmetu, etickej zodpovednosti a jej postavenia mimo normálnych hraníc detskej literatúry. ${ }^{4}$ Zároveň musí byt' historicky presná, aby nemohlo dôjst’ zo strany recipientov $\mathrm{k}$ popieraniu udalostí zobrazených $\mathrm{v}$ narácii.

Z týchto dôvodov plní vo velkej miere edukatívnu funkciu so zámerom zabránit’ šíreniu antisemitských, xenofóbnych prejavov v spoločnosti rozširovaním povedomia o dôsledkoch nenávisti voči inakosti (voči „tým druhý“) od detského veku. Kvetka Dašková v úvodnom slove k slovenskému vydaniu Dávidkovho denníka (2016) akcentuje fakt opätovného narastania antisemitizmu na Slovensku, resp. vo svete.

2 Tematikou antisemitizmu a holokaustu v slovenskom filme sa zaoberá Štefan Timko. Pozri: TIMKO, Š.: Perzekúcia židovského obyvatelstva a holokaust v povojnovej slovenskej kinematografii. In: Slovenské divadlo. Revue dramatických umení, 2021, č. 2, s. 128 - 143.

3 KOKKOLA, L.: Representing the Holocaust in Children's Literature. New York - London: Routledge, 2003, S. 1.

4 Ibid., s. 11. 
Zároveň zdôvodňuje potrebu vydávania kníh podobného zamerania: „Robíme tak preto, že v Tvojom rodnom Pol’sku $i$ v našej krajine, no aj inde v Európe sa opät objavujú skupiny ludí, vel'mi často i vel'mi mladých, ktorí zmýšlajú podobne ako vtedy dávno nemeckí fašisti a nacisti, aj tí Poliaci a Slováci, čo ich u Vás i u nás nasledovali. "5

Okrem edukatívnej a dokumentárnej funkcie textu treba akcentovat' aj funkciu umeleckú. Pri výbere jazykových prostriedkov sa v analyzovaných dielach prejavuje autorský individuálny štýl. Vincent Šikula je v slovenskom literárnom prostredí známy ako autor literatúry pre deti a mládež, preto vel’mi citlivo pracuje so slovom a komunikuje tragiku holokaustu bez negatívneho pátosu. Tragikou je poznačený štýl amatérskeho autora Dávida Rubinowicza, rovnako aj dielo Juraja Špitzera Biele oblaky. Hoci je autor v slovenskom literárnom prostredí vnímaný skôr ako esejista (jeho kniha esejí Nechcel som byt žid je jedinou autorovou knihou, ktorá vyšla v reedícii a je známa slovenskému čitatelovi), v uvedenom diele sa prejavil ako beletrista s jedinečným štýlom. Tragickost' doby odlahčil bohatou symbolikou a umeleckými opismi prírody, jej personifikovaním: „Slunce se sklánělo $k$ západu, vystřelovalo do jehličnatého lesa poslední paprsky a ozařovalo nedalekou zř́ceninu hradu. "6 Príroda samotná však nie je priamou súčast’ou deja (ako k zobrazovaniu prírody pristupovali predstavitelia prózy naturizmu). Fiktívnou postavou narácie sa stávajú len biele oblaky.

Grosmanov štýl je pri zobrazovaní antisemitizmu a holokaustu velmi špecifický. V porovnaní s inými dielami slovenskej proveniencie s tematikou šoa, v ktorých autori akcentujú hrôzy masového vyvražd’ovania židovskej minority (memoárová literatúra často priam naturalisticky) a existenciálny dopad na životy preživších, Grosman vniesol do svojej tvorby určitú komickost', resp. tragikomickost’. Táto črta Grosmanovej tvorby o holokauste sa výrazne prejavila v novele Nevesta, a o to viac v románe $Z$ pekla štěstí, ktorého hlavný hrdina ako komentátor ${ }^{7}$ prežitých udalostí sa pre svoje pudy dospievajúceho chlapca často dostáva do humorných situácií a náležite o nich rozpráva. Holokaust je v literatúre a filme často prezentovaný motívmi a metódami klasickej tragédie. Javí sa, že metódy komédie a smiechovej kultúry nie sú vhodné pre zobrazenie tejto problematiky. Napriek tomu sa prvky humoru objavujú v literatúre o holokauste. Židia sú charakteristickí svojím zmyslom pre humor, dokážu si dokonca zavtipkovat' aj o holokauste - dôkazom je napr. kniha Jána Kalinu Tisíc a jeden vtip (2019) či tvorba Tomáša Janovica. Humor sa v nacistických getách a táboroch stal nástrojom boja proti perzekúciám a poníženiu a prejavil sa aj v literárnych dielach slovenských a českých autoroch židovského pôvodu, ako napr. Emil Knieža, Ludvík Aškenazy

5 RUBINOWICZ, D.: Dávidkov denník. Bratislava: Vydavatelstvo Q111, 2016, s. 6.

6 ŠPITZER, J.: Bílá oblaka. Praha: Státní nakladatelství dětské knihy, 1964, s. 66.

7 Román $Z$ pekla štěstí je monológom Roberta Guta, ktorým sú prerozprávané aj dialógy medzi postavami. 
a Ladislav Grosman. Ich diela sú kombináciou židovského humoru a vtipov so zmesou komických, tragických a fraškovitých čŕt. ${ }^{8}$ Americký spisovatel Terrence Des Pres tvrdí, že niektorí spisovatelia zámerne použili humor ako prostriedok prelomenia tabu a snahy prinútit čitatela znovu premýšlat. ${ }^{9}$

Knihy pre deti a mládež s tematikou druhej svetovej vojny, ktoré sú predmetom interpretácie a komparácie, spája spoločný menovatel’ - hlavnými protagonistami sú deti. Rozdiel je v rozprávačovi príbehu, ktorým je bud’ samotný detský hrdina (Dávidkov denník, $Z$ pekla štěstí) alebo je jeho príbeh vyrozprávaný z pohladu svedka udalostí (z pohladu dietata - Erikine lalie alebo z pohladu dospelého človeka - Biele oblaky). Literatúra pre deti (predškolského veku a žiakov do 14 - 15 rokov) a mládež (15- 18 rokov) zahóňa intencionálne a neintencionálne diela, teda diela, ktoré boli zámerne alebo nezámerne vytvorené pre detského čitatela. Šikulovu poviedku Erikine lalie a dielo Juraja Špitzera Biele oblaky sú intencionálnymi dielami a možno ich explicitne zaradit' do detskej literatúry. Erikine lalie boli autorom zaradené do zbierky pre deti a mládež Rozprávky a rozprávania a v českom preklade Bielych oblakov je uvedená veková hranica čitatela 13 rokov. Dávidkov denník, hoci je denníkom chlapca (diet’ata) a v úvode sa Kvetka Dašková prihovára det’om, môže plnit’ estetickú a poznávaciu funkciu nielen pre detského, ale aj pre dospelého recipienta - podobne ako Denník Anny Frankovej. Napriek absentujúcim faktom, ktoré boli v slovenskom preklade doplnené Adamom Rutkowskim a Kvetou Daškovou (a ilustráciami Kataríny Slaninkovej), podáva subjektívne svedectvo doby metódou oral history. Špecifický je román Ladislava Grosmana, ktorý je príkladom neintencionálneho textu. $Z$ pekla štěstí doplńa autorovu triádu diel s tematikou holokaustu (Obchod na korze, Nevesta). Zacielením na detského (dospievajúceho) aktanta a výberom štylistických prostriedkov $\mathrm{s}$ častým výskytom slangových slov pokleslo dielo na úroveň príjemcu z radov dospievajúcej mládeže. $V$ porovnaní s ostatnými analyzovanými dielami je však tento román určený pre staršieho čitatela nad 15 rokov.

Hoci sa uvedené diela odlišujú z hladiska žánru aj rozprávača, spája ich spoločný názor - vojna a holokaust poznačili deti „tým najsurovejším spôsobom.“10 Naviac, všetky príbehy zachytené $\mathrm{v}$ týchto knihách vychádzajú z reality, z príbehov, ktoré sa odohrali počas druhej svetovej vojny. V prípade Dávidkovho denníka niet pochýb o autentickosti diela. Je to denník polského židovského chlapca, ktorý si svoje dojmy z vojny začal zapisovat' 21 . marca 1940 ako dvanástročný a posledný nedokončený zápis

8 HIEMER, E.-M. - HOLÝ, J. - FIRLEJ, A. - NICHTBURGEROVÁ, H. (eds.): Handbook of Polish, Czech, and Slovak Holocaust Fiction. Oldenbourg: De Gruyter, 2021, s. 31.

9 KOKKOLA, L.: Representing the Holocaust in Children's Literature. New York - London: Routledge, 2003, S. 9.

10 ŽILKOVÁ, M.: Holokaust očami detí. In: HRBÁCSEK, M. (ed.): Židovský kultúrny fenomén v stredoeurópskom kontexte III. Nitra: OZAJ, 2019, s. 7. 
je zo 6. júna 1942. Dávidko bol transportovaný do koncentračného tábora Treblinka 21. septembra 1942, v deň najväčšieho židovského sviatku Jom Kipur, a zahynul pravdepodobne 22. alebo 23. septembra v plynovej komore. Denník, ktorý možno považovat' za najpravdivejšiu a najsmutnejšiu kroniku neludského zaobchádzania, sa našiel na pôjde domu v Bodzentyne, ktorý bol posledným domovom jeho rodiny. Podáva obraz života v Pol’sku počas vojny, v ktorom postupne narastá psychický teror voči Židom vo forme protižidovskej propagandy, karikatúr alebo priamym ponižovaním. Dňa 12. februára 1942 si do denníka zapísal: „O dve hodiny nato sa strážnik znovu objavil a začal akýsi papier pribijat’na múr. Nebola to však vyhláška, lež karikatúry. [...] Nežidia sa tak rehotali, až ma z toho hlava rozbolela, že takúto pohanu a ponižovanie musia Židia znášat. Keby sa tie hanebnosti len čím skôr pominuli. "11 Denník je tak svedectvom nielen o neprávostiach, ktoré musela židovská minorita znášat', ale aj dôkazom dopadu týchto udalostí na detskú psychiku. Na inom mieste píše: „Neprejde ani jediný pokojný deň. Som z toho strašne nervózny a ako pomätený, ked' začujem o nejakom neštastí. "12 Podobné negatívne konotácie k vojne a prenasledovaniu Židov sú príznačné pre celý denník. Dávidko len výnimočne spomína radostné udalosti napr. stretnutie s líškou zo dňa 3. júla 1940: „Ako sme tak zbierali drevo, zazreli sme lišku. Aj sme sa trošku zlakli, ale liška sa bála viac ako my jej a ufujazdila. Boli sme štastní, že sme ju uvideli. "13

Grosmanov román $Z$ pekla štěstí je príbehom štrnást'ročného dospievajúceho chlapca. Robert Gut vyrastal vo východoslovenskom mestečku pod Vihorlatom v Humennom, ktoré je aj autorovým rodným mestom. Život židovského chlapca bol poznačený holokaustom, pričom rodičia sa snažili zachránit' svoje diet’a poslaním do Mad’arska. Robert sa v Mad’arsku vel’akrát sám pretíka životom vyzbrojený len znalost’ou rodokapsov a príbehov z červenej knižnice, pričom často balansuje medzi životom a smrt’ou. Z tohto aspektu by sa mohlo zdat', že dopad vojnových udalostí na jeho psychiku nebol v takej výraznej miere ako v prípade Dávidka. Smutné, dojemné momenty sú odlahčené humornou vsuvkou - napr. pri rozlúčke s matkou pred odchodom na vlak, ktorý ho mal odviezt’ do Madarska, píše: „maminka mne líbala na čelo a nos a všude, a měla teplou tvář, vlhkou a říkala zajíkavě, jen kdybych věděla, že budeš na sebe dávat pozor. “14 Následne píše: „už cestou na nádraží jsem dokázal oběma Blumovic holkám, které jely do Mad’arska se mnou, že jsou pitomé káči a že mluví nesmysly. "15

11 RUBINOWICZ, D.: Dávidkov denník. Bratislava: Vydavatel'stvo Q111, 2016, s. 44.

12 Ibid., s. 58.

13 Ibid., s. 21.

14 GROSMAN, L.: Z pekla štěstí. In: Spisy Ladislava Grosmana 1. Praha: Akropolis, 2020, s. 173.

15 Ibid. 
Vincent Šikula zachytil v poviedke pre deti Erikine lalie z knihy Rozprávky a rozprávania príbeh židovského dievčatka Eriky Grossovej. Zobrazil príbeh reálnej rodiny, ktorá žila počas vojny v jeho rodnej obci, v Dubovej pri Modre. Otec Samuel, matka Elza a ich dcéry Laura a Erika boli transportovaní do koncentračného tábora Auschwitz v roku 1942. Otec bol zavraždený v tábore ako 51-ročný v roku 1942, pravdepodobne aj matka Elza, hoci rok jej zavraždenia sa nepodarilo s istotou zistit'. Laura zomrela ako 19-ročná taktiež v roku 1942. A Erika bola podl’a oficiálnych dokumentov zavraždená v tom istom roku ako 13-ročná. Podla svedectva jednej z preživších Židoviek, ktorá s ňou bola v jednom baraku, však Erika zomrela až pred oslobodením tábora v roku 1945. Zostali po nej v obci len kvety, a to najmä lalie: „Dodnes v Dubovej rastú a každý rok kvitnú, rastú a kvitnú lalie štrnástročnej Eriky Grossovej."16

Dielo Juraja Špitzera Biele oblaky, ktoré je v súčasnosti nedostupné na slovenskom knižnom trhu a dalo by sa povedat', že upadá do zabudnutia, sa od ostatných odlišuje tematickým zameraním. Tvorba tohto autora židovského pôvodu akcentuje pretrvávajúci antisemitizmus aj v období krátko po skončení vojny, resp. do 90. rokov 20. storočia (Špitzer zomrel v roku 1995) s predikciou gradovania nenávistných prejavov voči židovstvu. V „rozprávke“ Biele oblaky však zobrazil tematiku Slovenského národného povstania, ktoré bolo podla neho možnost’ou pre Židov bránit’ sa proti fašistickej presile so zbraňou v ruke. Juraj Špitzer napísal najskôr scenár k filmu, ktorý bol následne realizovaný (1962, réžia: Ladislav Helge). Až potom sa rozhodol pre knižné vydanie príbehu o najmladšej slovenskej partizánke, len desatročnej Aničke Steinerovej. Špitzer si kladie za ciel neustále sa vo svojich knihách vracat' k tým, ktorí sa stali obet’ami vojnovej mašinérie a podat' tak svedectvo o ich živote, aby neupadli do zabudnutia. Treba v tejto súvislosti spomenút, že Špitzer ako jediný z jeho primárnej rodiny prežil vyhladzovanie židovskej minority. Na smrt’ rodičov reaguje: „Môj život sa roztrhol, polovica z neho odpadla, ako ked' sa lámu ladovce. " ${ }^{17}$

Ústrednou témou knihy je umelecké, do určitej miery fiktívne vykreslenie posledných dní života Aničky Steinerovej (postava Zuzanky). Spomienka na ňu - útle dievčatko s mandlovými očami ${ }^{18}$ - sa dostala aj do Špitzerovej knihy Nechcel som byt žid. Po bojoch pri Gápli zachránila život partizána pred vykrvácaním a v preoblečení za žobrákov putovali na Vtáčnik - miesto zrazu partizánskych jednotiek. Svoju smrt’ našla v obci Cigel’ v gazdovskom dome, v ktorom ju zanechali. Príčinu a okolnosti jej smrti sa nikdy nedozvedeli.

16 ŠIKULA, V.: Erikine lalie. In: RICHTER, M. (ed.): Božia ulička. Antológia slovenskej literatúry o holokauste. Bratislava: Vydavatel'stvo spolku slovenských spisovatelov, 1998, s. 123.

17 ŠPITZER, J.: Nechcel som byt žzid. Bratislava: Kalligram, 1994, s. 61.

18 Ibid., s. 250. 


\section{Symbolika detskej nevinnosti}

Zuzka v Špitzerových Bielych oblakoch sa pre autora stala onomastickým symbolom detskej nevinnosti a zároveň strateného detstva. Na vykreslenie jej detskej čistej duše bez poškvrny využíva autor symboliku bielej farby, čo naznačuje aj samotný názov diela. Biela je hmla, opar z hôr, ktorý sprevádza Zuzanku a Petra na ceste horami. Biele sú oblaky, ktoré im poletujú nad hlavami, a biely je aj sneh, na ktorom Zuzanka zomiera. Krátko pred smrtou pozoruje zo senníka modrú oblohu, po ktorej plávajú biele oblaky a hrá sa s nimi fiktívnu hru: „Po obloze plula oblaka. Přimhouřila oči proti ostrému slunečnímu světlu a pozorovala vzdušné lodě. Zaujaly ji tvary oblak. Mít tužku a papír, tak by si je nakreslila [...] Vitr si hraje pod modrou oblohou a já si budu hrát s ním. Budu hádat, co vítr $z$ oblak udělá a jak je potom zase přemění."19

Hra s oblakmi ju vrátila na pár okamihov do detstva, do detskej bezstarostnosti. O chvílu našla svoju smrt' - oblaky zostali jej poslednými spoločníkmi:

„Opět se nad ní klenula oslnivě modrá obloha s letícími bílými oblaky. Na tváři se jí objevil smutný úsměv.

,Letí ke slunci, ' rekla tiše.

Byla to její poslední slova." 20

V priebehu deja, počas putovania s Petrom, sa Zuzanka túžila vrátit’ domov a nájst' svojich rodičov, hoci bol ich dom vypálený Nemcami a rodičia pravdepodobne mŕtvi. V jej predstavách a snoch to mali byt’ oblaky, na ktorých priletí domov. Autor v poetickom vykreslení konca jej života predznačil metaforické, spirituálne spojenie Zuzankinej duše s oblakmi, ktoré ju priviedli k slnku, k rodičom do nebeského domova.

Na rozdiel od Zuzanky bola Erika zo Šikulovej poviedky židovského pôvodu, hoci ona a aj jej rodina žili životom asimilovaných židov. Erika spoločne s katolíkmi slávila krest’anské sviatky, najmä sviatok Božieho tela, počas ktorého sa stavajú oltáre zdobené laliami. Zároveň sa Eriku počas holokaustu snažili rodičia zachránit’ prijatím krest’anského krstu.

Šikula, rovnako ako Špitzer, poukazuje na detskú nevinnost’ na pozadí vojnového besnenia. Namiesto symboliky bielej farby však využíva symbol lalie - biblický symbol Panny Márie a zároveň symbol čistoty, v tomto prípade čistoty malého (alebo skôr dospievajúceho) židovského dievčat’a, ktoré sa stalo obet’ou holokaustu. Neprevinila sa ničím, jej duša aj život boli čisté. Previnila sa len tým, že sa narodila ako Židovka. Na rozdiel do Aničky Steinerovej, na ktorú zostali reminiscencie len v tvorbe Juraja Špitzera, rodina Grossových má svoj pamätník aj v obci, v ktorej žili. V obci Dubová boli v auguste 2015 osadené v chodníku na Hlavnej ulici pred ich domom pamätné kamene - Stolpersteine pripomínajúce ich tragédiu. Nenápadné pripomienky na túto

19 ŠPITZER, J.: Bílá oblaka. Praha: Státní nakladatelství dětské knihy, 1964, s. 112.

20 Ibid., s. 113. 
židovskú rodinu sa nachádzajú len pár metrov od rodného domu Vincenta Šikulu, na ktorom je umiestnená pamätná tabula, dielo akademického sochára Jozefa Barinku.

\section{Motív strateného detstva}

V literatúre pre deti a mládež s tematikou vojny a holokaustu je často sa opakujúcim aspektom motív strateného detstva, $v$ ktorom je vyjadrená celá tiaž prežívania detského hrdinu v nepriaznivých podmienkach a strach o vlastné prežitie. Špitzerova kniha Biele oblaky je okrem iného reflexiou nad dopadom vojny na život detí, ktorých život „vyhasol skôr než sa mohol rozvinút. " 21 Je príbehom mnohých iných detí, ktoré počas života poznali „iba strach z tmy, zo zlých ludí, hrôzu vybuchujúcich granátov, dážd' a zimu. "22 Vojna ich pripravila o detstvo, robila ich predčasne dospelými.

Autor akcentuje dôležitost' detského hrdinu, ktorý sa pre neho stáva symbolom nezmyselnosti vojny a zabíjania maloletých, aj zaradením knihy do žánru rozprávky. Jeho postavy ,jako by byli z pohádky. Ale všechny pohádky vznikají z událostí, které se opravdu staly. Také tahle. "23 Špitzerova definícia je v rozpore s definovaním rozprávky podla Tibora Žilku, podla ktorého sa tento žáner zakladá na vymyslenom príbehu, neviaže sa ku konkrétnemu priestoru a času. ${ }^{24}$ Autorove zaradenie knihy medzi rozprávky možno chápat’ ako jeho snahu o demonštrovanie, že hoci je príbeh reálny a reálne možný, mohol sa odohrat mimo času a priestoru, do ktorého ho autor zasadil kdekolvek na svete, $v$ akomkolvek čase a akémukolvek inému diet’atu. Zaradením fiktívnych prvkov do príbehu Aničky Steinerovej posúva príbeh do roviny nereálnosti, resp. pravdepodobnosti. Z týchto ohladov sa dielo približuje realistickej rozprávke, v ktorej sa strácajú fantastické prvky a nahradzujú ich realistické. Tragický, neštastný záver hlavnej postavy, pochmúrny dej evokuje skôr k žánru balady. Avšak autorovo zaradenie príbehu do žánru rozprávky možno chápat’ skôr metaforicky, kedže hlavnou hrdinkou je dieta.

Stratené detstvo Eriky Grossovej vysvetluje Šikula z pohladu nežidovského chlapca rozprávača príbehu. Ich židovská kamarátka im akoby zo dňa na deň vymizla zo života, musela žit v ústraní, bez kontaktov s kamarátmi. Autor ako malý chlapec nechápal, čo sa okolo jeho kamarátky, židovského dievčat’a, deje. Prečo sa s ním viac nestretáva, hoci boli predtým kamaráti. Vysvetloval si to svojím detským spôsobom. „Začala sa mi vyhýbat'. A ja som si myslel, že to asi preto, lebo je teraz zbožnejšia než ja a nechce sa už so mnou stretávat. “" ${ }^{25}$ Následne píše: „Žeby jej pán farár Hotka zakázal stretávat”

21 ŠPITZER, J.: Nechcel som byt žid. Bratislava: Kalligram, 1994, s. 250.

22 Ibid., s. 250.

23 ŠPITZER, J.: Bílá oblaka. Praha: Státní nakladatelství dětské knihy, 1964, s. 7.

24 ŽILKA, T.: Vademecum poetiky. Nitra: Univerzita Konštantína Filozofa, 2011, s. 315.

25 ŠIKULA, V.: Erikine lalie. In: Bibiana, 2006, č. 3, s. 49. 
sa so mnou? L'udia predsa povedali, že pán farár chce Eriku zachránit. Hádam len nie predo mnou? "26 Hoci autor príbeh napísal ako dospelý, dokázal sa majstrovsky vžit’ do pozície chlapca, ktorý nevidí rozdiel medzi židovskou a nežidovskou krvou.

Roberta Guta z Grosmanovho románu zastihla vojna a holokaust v čase dospievania. V úvodných častiach knihy sa zdá, akoby sa ho jednotlivé dejinné udalosti v súvislosti s prenasledovaním židovskej minority priamo bytostne nedotýkali. Zachytáva síce prejavy antisemitizmu, ktoré sa ho dotkli najmä zákazom navštevovat’ školu, avšak nútený odchod do Mad’arska pre svoju záchranu, internovanie v gete, ako aj všetky ostatné skúsenosti prežíva s istým nadhladom. V každej udalosti nachádza aj kúsok radosti. V záverečnej časti druhej kapitoly, ked' ho nemecký vojak vezie naspät' domov, píše: „a nakonec jsem se vezl domů jako pán na plošině vojenského nákladního auta, ano, na plošině německého vojenského auta jsem se vracel domů po tolika létech a volal jsem z plna hrdla hurá - hurá - máj - máj - máj!“27 K zlomu dochádza v tretej, poslednej kapitole, ktorá je jeho návratom k rodičom na Slovensko a počas ktorej zažil aj fyzické útoky, napr. zo strany policajta: „mlátil mne surovec, málem mi zuby vyrazil a snad by mne zabil nebýt lékárníka, který ho prosil, at’ už toho nechá, že jsem máloletý, že by mne mohl zabit. " 28 V závere knihy po hrôzach, ktoré Robert zažil najmä pri svojej ceste na Slovensko, badat' už v jeho myslení istú dávku pesimizmu. Začína si postupne uvedomovat' dopad vojny nielen na svoj život, ale aj na iné deti, resp. na bytie ako také. Pri rieke, pri ktorej sa nežidovskí chlapci pokojne hrali futbal, konštatuje: „Kluci tu hráli fotbal na trávníku. Moc jsem se divil, že jsou ještě kluci, co hrají fotbal, a že trávník je zelený. "29 V závere knihy je už evidentný prerod Roberta z dospievajúceho, detsky hravého a naivného chlapca, ktorý zažíva prvé pletky s dievčatami, na silného jedinca vykazujúceho prvky správania dospelého človeka, ktorý sa zároveň stáva oporou pre iných dospelých napriek vlastnej životnej tiaži. Jeho reakcia na správu o deportácii jeho rodičov a brata Mikiho je dôkazom tohto prerodu: „Slova jsem nevyřkl. Slzu neuronil. V̌̌emu jsem najednou porozuměl... Paní Mašlejová ničemu nerozuměla... zadrhávala se $v$ řěi, moc plakala, moc se omlouvala, jako kdyby to udělala ona, jako kdyby to byla ona, kdo před několika málo hodinami naložila našeho tatínka, naši maminku a Mikiho do dobytčího vagonu a odvezla do tábora smrti..., do Osvětimi nebo do Treblinky nebo do Majdanku nebo ví bůh kam... Nemohl jsem ji utišit. "30

Na rozdiel od Roberta Guta si Dávidko plne uvedomuje všetky udalosti, ktoré sa odohrávajú v jeho bezprostrednej blízkosti. Jeho denník je komplexnou plejádou

26 Ibid.

27 GROSMAN, L.: Z pekla štěstí. In: Spisy Ladislava Grosmana 1. Praha: Akropolis, 2020, s. 288.

28 Ibid., s. 304 .

29 Ibid., s. 325 .

30 Ibid., s. 334 . 
všetkého, čím pol'skí Židia trpeli počas vojny. Každodenne je konfrontovaný so smrtou. Spočiatku sa ho velmi citlivo dotýkali informácie o vraždení Židov. Po prvých správach zo dňa 12. decembra 1941 si do denníka zapísal: „Včasráno žandári stretli na ceste jedného Žida, ktorý išiel von z mesta, a rovno ho zastrelili, len tak, pre nič za nič. Nato sa pohli d’alej a zastrelili ešte jednu Židovku, zase len tak, pre nič za nič. Tak prišli bez prićiny o život dve obete. Ked’ som sa vracal domov, velmi som sa bál, aby som žandárov nestretol, ale mal som štastie. "31 Plynutím času a pribúdajúcimi obetami si postupne na to zvykol a ku koncu denníka už len konštatuje počet obetí. Okrem samotného vraždenia sa ho však bytostne dotýkali aj prejavy antisemitizmu. Po návšteve richtára 16. januára 1942 je v denníku napísané: „Richtár potom vravel, že všetkých Židov treba postrielat', pretože sú to nepriatelia. Keby som chcel hoci len niečo napisat z toho, čo u nás richtár pohovoril, nie, nemôžem... "32 Dávidkove denníkové zápisky pritom vyznievajú akoby boli písané dospelým človekom. Surovosti, ktorých bol svedkom, ho doviedli $\mathrm{k}$ predčasnej dospelosti a vytriezveniu z bezstarostných detských čias.

Hoci však Dávidkov prejav a konanie evokujú dospelého človeka, v istých momentoch sa prejavuje zmýšlanie chlapca. Ked ho raz otec nespravodlivo zbije, zápis je výčitkou a obžalobou otca, že ho v skutočnosti nelúbi. O pár dní odvážajú otca na nútené práce a Dávidko za ním pocíti obrovský smútok a lásku, ktorú mu dával: „Vtedy ma prepadol zúfalý plač, vtedy som pocítil, ako velmi mám otecka rád, aj on mña, vtedy som precítil, že to, čo som napísal 1. mája, že ma nelúbi, je škaredá lož. [...] Dlho som tak plakal a nemohol sa utíšit', najmä ked' som si pripomenul oteckovu uplakanú tvár. Koho sme mali najdrahšieho na svete, toho nám vzali... “33

\section{Na záver}

Autentické príbehy židovských aj nežidovských detských hrdinov, ktorí vyrastali $\mathrm{v}$ tragických podmienkach vojnových čias a konečného riešenia židovskej otázky, zachytených v literatúre pre deti a mládež, sú obrazom dopadu týchto udalostí 20. storočia na život detí. Okrem Roberta Guta z Grosmanovho románu $Z$ pekla štěstí sa životy týchto detských postáv skončili tragicky. Bez ohladu na to, či vojnu prežili alebo nie, doba, v ktorej žili, ich pripravila o právo na detstvo. Vynára sa otázka či bola ich smrt' tragédiou alebo vykúpením. Existenciálne problémy, ktoré sa prejavovali u preživších v povojnovom období, velmi úzko súvisia práve s neustálym strachom a blízkost’ou smrti, ktorej boli vystavení počas vojny. Leopold Lahola v poviedke Rozhovor v prvej osobe spája prežitie Židov s mŕtvou existenciou: Tieto motívy vložil do postavy mladého lekára, ktorý sa aj napriek tomu, že prežil šoa, snažil zomriet'.

31 RUBINOWICZ, D.: Dávidkov denník. Bratislava: Vydavatel'stvo Q111, 2016, s. 30.

32 Ibid., s. 39.

33 Ibid., s. 72. 
Svoje bytie pokladal za skazené: „..ja sám som to, čo nie je v poriadku. Som pokazený. Jedných smrt’ vzala, iných načisto pokazila [...] Nežijeme, my sme iba ostali nažive. A to je rozdiel. "34 Pocity osobnej skazenosti sú navyše umocnené pocitmi viny za vlastné prežitie na úkor tých, ktorí sa stali obet’ami vojny a šoa. Pavel Traubner v prológu ku knihe Ivany Havranovej Odvlečení píše: „Dlhé nasledujúce roky som sa spotený budil na nočnú moru a strašné výčitky, prečo práve ja som prežil a tisícky mojich detských rovesníkov, ktorí sa previnili iba tým, že boli Židia, skončili v plynových komorách a vyleteli ako sadze komínmi krematórií. Ba čo viac, niekedy ma táto výčitka schytí $i$ po sedemdesiatich piatich rokoch od môjho narodenia. "35 V tejto súvislosti sa vynára dôležitost’ a potreba vydávania kníh pre deti a mládež s tematikou vojny a holokaustu, pretože majú ambíciu slúžit' ako edukatívna pomôcka s cielom osvetlit' detskému čitatelovi dopad negatívnych javov v spoločnosti na prežívanie a život diet’at’a a zároveň dopomôct' $\mathrm{k}$ akceptovaniu inakosti a uvedomeniu si, kam až môže zájst’ stereotypizácia spoločnosti a nenávist’ voči tým druhým.

\section{Literatúra:}

GROSMAN, L.: Z pekla štěstí. In: Spisy Ladislava Grosmana 1. Praha: Akropolis, 2020, s. 163 - 334. ISBN 978-80-7470-296-9.

HAVRANOVÁ, I.: Odvlečení. Bratislava: Marenčin PT, 2017. ISBN 978-80-8114-852-1. HIEMER, E.-M. - HOLÝ, J. - FIRLEJ, A. - NICHTBURGEROVÁ, H. (eds.): Handbook of Polish, Czech, and Slovak Holocaust Fiction. Oldenbourg: De Gruyter, 2021. ISBN 978-3-11-066725-7.

KOKKOLA, L.: Representing the Holocaust in Children's Literature. New York - London: Routledge, 2003. ISBN 0-415-93719-1.

LAHOLA, L.: Posledná vec. Bratislava: Slovenský spisovatel', 1968.

RUBINOWICZ, D.: Dávidkov denník. Bratislava: Vydavatel’stvo Q111, 2016. ISBN 978-80-89092-77-2.

ŠIKULA, V.: Erikine l'alie. In: Bibiana, 2006, č. 3, s. 48 - 50. ISSN 1335-7263.

ŠIKULA, V.: Erikine l’alie. In: RICHTER, M. (ed.): Božia ulička. Antológia slovenskej literatúry o holokauste. Bratislava: Vydavatel'stvo spolku slovenských spisovatel'ov, 1998, s. 121 - 124. ISBN 9788088735816.

34 LAHOLA, L.: Posledná vec. Bratislava: Slovenský spisovatel', 1968, s. 180.

35 HAVRANOVÁ, I.: Odvlečení. Bratislava: Marenčin PT, 2017, s. 6. 
ŠPITZER, J.: Bílá oblaka. Praha: Státní nakladatelství dětské knihy, 1964. ŠPITZER, J.: Nechcel som byt žid. Bratislava: Kalligram, 1994. ISBN 80-7149-047-4. TIMKO, Š.: Perzekúcia židovského obyvatelstva a holokaust v povojnovej slovenskej kinematografii. In: Slovenské divadlo. Revue dramatických umení, 2021, č. 2, s. 128 - 143. ISSN 0037-699X. DOI: 10.31577/sd-2021-0009.

ŽILKA, T.: Vademecum poetiky. Nitra: Univerzita Konštantína Filozofa, 2011, $426 \mathrm{~s}$. ISBN 978-80-8094-963-1.

ŽILKOVÁ, M.: Holokaust očami detí. In: HRBÁCSEK, M. (ed.): Židovský kultúrny fenomén v stredoeurópskom kontexte III. Nitra: OZAJ, 2019, s.7-20. ISBN 978-80-973-283-0-6.

\section{About the author}

\section{Monika Adamická}

Constantine the Philosopher University in Nitra, Faculty of Central European Studies, Institute of Languages and Cultures of Central Europe, Nitra, Slovakia

monika.adamicka@ukf.sk

https://orcid.org/0000-0002-4932-9603 